\title{
Mortality risk in men is associated with a common mutation in the methylene- tetrahydrofolate reductase gene (MTHFR)
}

\author{
B astiaan T H eijmans ${ }^{1,2}$, Jacobijn G ussekloo ${ }^{2}$, Cornelis K luft $^{1}$, Simone D roog ${ }^{1}$, \\ A M argot Lagaay ${ }^{2}$, Dick L K nook ${ }^{1,2}$, Rudi GJ Westendorp ${ }^{2,3}$ and Eline P Slagboom ${ }^{1}$ \\ ${ }^{1} G$ aubius $L$ aboratory, TNO Prevention and $\mathrm{H}$ ealth, L eiden \\ ${ }^{2}$ Section of Gerontology and G eriatrics, Department of G eneral Internal M edicine, L eiden University M edical Center \\ ${ }^{3} \mathrm{D}$ epartment of Clinical E pidemiology, L eiden U niversity M edical C enter, L eiden, The N etherlands
}

\begin{abstract}
An elevated level of homocysteine in plasma is associated with the occurrence of cardiovascular disease. A common ala-to-val mutation in the methylenetetrahydrofolate reductase gene (MTHFR) is associated with an elevated level of plasma homocysteine. We studied the possible detrimental effects of the MTHFR mutation on mortality. Within a population-based study in the city of Leiden, the N etherlands, we first compared the MTH FR genotype distribution among 365 elderly subjects aged 85 years and over born in Leiden, and 250 young subjects aged 18 to 40 years whose families originated from the same geographical region. Second, the complete cohort of 666 subjects aged 85 years and over was followed over a period of 10 years for all-cause and cause-specific mortality and stratified according to MTHFR genotype. The frequency of the MTHFR mutation was significantly lower in the elderly than in the young $(0.30$ and 0.36 , respectively; $P=0.03)$. The difference in genotype distribution was only present in men. The estimated mortality risk up to 85 years in men carrying the val/val genotype was 3.7 (95\% confidence interval (CI), 1.3-10.9). 0 ver the age of 85, mortality in men with the val/val genotype was increased 2.0-fold (95\% Cl, 1.1-3.9) and appeared to be attributable to cancer rather than cardiovascular causes of death. A mong women aged 85 years and over, no deleterious effect of the MTH FR mutation was observed. In conclusion, the MTHFR mutation is associated with increased mortality in men in middle and old age, but not in women.
\end{abstract}

Keywords: methylenetetrahydrofolate reductase; mortality; cardiovascular diseases; cancer; homocysteine; longevity genetics; ageing

Correspondence: Eline P Slagboom, PhD, Gaubius Laboratory, TNO Prevention and Health, PO B ox 2215, 2301 CE Leiden, The Netherlands. Tel: +31715181406; Fax: +31715181904; E-mail: p.slagboom@pg.tno.nl

R eceived 13 A ugust 1998; revised 100 ctober 1998; accepted 21 October 1998 


\section{Introduction}

A $n$ elevated level of homocysteine in plasma is associated with the occurrence of cardiovascular disease ${ }^{1}$ and increased mortality in patients with coronary artery disease. ${ }^{2} \mathrm{~A}$ recent meta-analysis estimated that every $5 \mu \mathrm{mol} / / \mathrm{l}$ increment in plasma homocysteine increases the risk of coronary heart disease by $60 \%$ for men and $80 \%$ for women. ${ }^{1}$ Homocysteine is formed when the methyl-group of methionine is transferred to DNA, proteins or other molecules. The basal level of plasma homocysteine is mainly determined by the remethylation of homocysteine to methionine. ${ }^{3,4}$ This reaction is regulated by the enzyme methylenetetrahydrofolate reductase (MTHFR) ${ }^{3}$ which converts 5,10-methylenetetrahydrofolate to 5-methyltetrahydrofolate. The methionine/homocysteine metabolism is disrupted by deficiencies in the essential coenzymes vitamin B 6, B 12 and folate, and by homozygosity for rare mutations in the genes encoding MTHFR and cystathionine $\beta$ synthase. ${ }^{5,6}$ These genetic defects give rise to greatly elevated homocysteine levels in plasma and result in mental retardation, bone malformations and premature atherosclerotic disease. ${ }^{5,6}$

$\mathrm{R}$ ecently, a common $\mathrm{C}_{677}$-to-T (ala-to-val) mutation in the MTHFR gene was identified ${ }^{7}$ which leads to a less severe disturbance of the methionine/homocysteine metabolism. A bout half the general population carries at least one mutated allele and the frequency of the homozygous mutated genotype (val/val) varies from $8 \%$ to $18 \%$ depending on the population..$^{8-19}$ The MTHFR mutation was shown to render the enzyme thermolabile, and homozygotes and heterozygotes had about a $70 \%$ and $35 \%$ reduced MTHFR activity, respectively. ${ }^{7}$ F urthermore, homozygosity for the mutation is associated with elevated levels of homocysteine in plasma. ${ }^{7,9,11,15-17,19-21}$ This association is dependent on age ${ }^{15,17}$ and nutrition. Plasma homocysteine levels are predominantly elevated among carriers of the val/ val genotype who have a low level of plasma folate. ${ }^{9,11,15}$ Moreover, it was shown that especially in $\mathrm{val} / \mathrm{val}$ carriers the level of plasma homocysteine was lowered by folic acid supplementation. ${ }^{22}$ In various reports the MTHFR mutation has been implicated in the risk of cardiovascular disease $\mathrm{A}^{410,14-16,18,19,21,23-28}$ and cancer ${ }^{12,29}$ but the data are equivocal.

To explore the possible detrimental effects of a disturbed methionine/homocysteine metabolism, we studied the association between the MTHFR mutation and mortality, nested in a population-based study of subjects aged 85 years and over (L eiden 85-plus Study).
This was done (i) in a cross-sectional analysis comparing the occurrence of the MTHFR mutation between subjects aged 85 years and over and young subjects aged 18-40years whose families originated from the same geographical region as the elderly subjects, and (ii), prospectively, over a 10-year follow-up period in the entire elderly cohort. The follow-up study included the analysis of cause-specific mortality risks.

\section{Materials and Methods}

The Leiden 85-plus Study is a population-based study in which all inhabitants of L eiden aged 85 years and over were invited to take part. ${ }^{30}$ of a total of 1258 eligible subjects, 221 died before enrolment which lasted from 1 D ecember 1986 to $1 \mathrm{M}$ arch 1988. Of the 1037 remaining subjects, 977 (94\%) participated and were medically interviewed at home. ${ }^{31} \mathrm{~A}$ fter the exclusion of subjects with a non-Dutch $(n=29)$ or unknown $(n=69)$ place of birth, sufficient cell material was available from 666 (188 men, 478 women) subjects for the present genetic study. DNA was extracted ${ }^{32}$ and MTHFR genotypes were determined by the PCR -amplification of a $198 \mathrm{bp}$ fragment containing the $\mathrm{C}_{677}$-to-T transition, followed by digestion with $\mathrm{Hinfl}$ as previously described. ${ }^{7}$ The MTHFR genotype was independently assessed by two observers. A s a standard laboratory procedure a randomly chosen $10 \%$ of the samples was reamplified. No genotyping errors were observed. The study was approved by the M edical $E$ thics Committee of L eiden U niversity and informed consent was obtained from all participants.

\section{Cross-sectional Analysis}

MTHFR genotype distributions were compared in elderly subjects aged 85 years and over and young controls. The subjects in the elderly population are survivors of a cohort born between 1887-1901. To avoid false associations with the MTHFR mutation due to differences in geographical origin rather than age, the cross-sectional comparison of elderly and young subjects accounted for local variations in MTHFR genotype distribution that may have existed in the past. Subjects aged 85 years and over who were born in Leiden $(n=365 ; 56 \%)$ were compared with a control population which consisted of 250 (139 men, 111 women) blood donors aged 18-40years of Dutch descent with either one parent born in L eiden and the other within $12 \mathrm{~km}$ of L eiden, or with two Leiden-born parents. Information regarding the birthplace of their grandparents was obtained from a written questionnaire. If a specific L eiden M THFR genotype distribution had existed in the past, the genotype distribution in young controls would have increasingly deviated, the greater the number of their L eiden-born grandparents. The upper age limit of the young controls was chosen since selection against genotypes contributing to population mortality was not expected to occur before the age of 40 years.

\section{Prospective Follow-up Study}

A II participants in the Leiden 85-plus Study were followed up for mortality until 10 ctober 1996. A mong the 666 subjects of the cohort studied, two were lost to follow-up. Primary causes of death were assessed by linking the death certificate 
numbers, obtained from civic registers, to the causes of death as recorded by the D utch Central Bureau of Statistics. Causes of death were classified according to the ninth revision of the International Classification of D iseases (ICD-9). ${ }^{33}$ D eath certificates from 1996, coded according to the tenth revision of the International Classification of D iseases, were recoded according to the ninth revision. ICD -9 codes were reviewed and each code was categorised for cardiovascular disease (ICD -9 390-459), cancer (ICD-9 140-239) and all causes (ICD -9 000-999). Death from infection was coded as previously described. ${ }^{34}$

\section{Statistical Analysis}

Differences in baseline characteristics were tested for significance with the $\chi^{2}$ test for categorical and Student's t-test for continuous variables. In the cross-sectional analysis, distributions of alleles and genotypes were compared by the $\chi^{2}$ test, and mortality risks and $95 \% \mathrm{CI}$ s were estimated using the exposure odds ratio. Mantel's extension of the Mantel$\mathrm{H}$ aenszel test was used to test for trend in stratified analyses. ${ }^{35}$ In the follow-up study, survival times for subjects were computed from the date of the home visit to the date of one of the following events: death from a specific cause, death from any cause, or 10 ctober 1996. Survival was estimated using the K aplan-M eier product limit method and compared with the log-rank test. A djusted mortality risks and $95 \% \mathrm{CIs}$ were estimated with Cox proportional hazards models. $C$ auses of death were assumed to be independent. $P$-values of less than 0.05 were considered to indicate statistical significance and all P-values were based on two-sided tests. The analyses were performed with the SPSS statistical software package.

\section{Results}

\section{Cross-sectional Analysis}

Table 1 shows the baseline characteristics of the study subjects from the cohort of Leiden inhabitants aged 85 years and over $(n=666)$. A gender difference was observed with respect to smoking habits, alcohol consumption and the prevalence of hypertension and cancer. The MTHFR genotype distribution in the complete cohort was $46.5 \%$ (ala/ala), $44.4 \%$ (ala/val) and $9.0 \%$ (val/val). For the cross-sectional analysis, MTHFR genotype frequencies in the elderly subjects born in Leiden ( $56 \%$ of the complete cohort) were compared with those in young subjects aged 18-40 years whose families originated from the Leiden area (Table 2). G enotype frequencies in both groups were in agreement with the distribution predicted by the $\mathrm{H}$ ardy-Weinberg equilibrium. The prevalence of the $\mathrm{val} / \mathrm{val}$ genotype in the control population $(12.4 \%$, $\mathrm{n}=250$ ) was consistent with the $10-18 \%$ reported for other populations greater than 200 subjects of E uropean, N orth-A merican and A ustralian origin..$^{8-13,15-17}$

The frequency of the val allele was significantly lower in elderly subjects than in young subjects ( 0.30 and 0.36 , respectively; $\chi_{\mathrm{df}=1}^{2}=4.74, \mathrm{P}=0.030$ ). This observation was illustrated by the over-representation of the ala/ala genotype (48.2\% vs $40.0 \%$ ) and the under-representation of ala/val (43.0\% vs 47.6$)$ and val/val genotype $(8.8 \%$ vs $12.4 \%)$ in elderly subjects as compared with young subjects.

Since the mortality and specific death causes differ between men and women, and the exposure to factors which potentially modulate the effects of the MTHFR mutation, may vary between men and women, the association was explored for men and women separately. The prevalence of the val/val genotype in elderly men was significantly lower than in elderly women $\left(4.4 \%\right.$ and $10.8 \%$, respectively; $\chi_{\mathrm{df}=1}^{2}=3.97$, $P=0.046)$, whereas the val/val frequency was virtually the same in young men and women $(12.2 \%$ and $12.6 \%$, respectively; $\left.\chi_{\mathrm{df}=1}^{2}=0.01, \mathrm{P}=0.93\right)$. Hence, the frequency of the ala/val and val/val genotypes were significantly reduced in elderly men as compared with

Table 1 Baseline characteristics of the 666 study subjects aged 85 years and over

\begin{tabular}{|c|c|c|c|c|}
\hline Characteristics & $\begin{array}{c}\text { All } \\
\text { subjects }\end{array}$ & Men & Women & $\begin{array}{l}\text { Test for gender } \\
\text { difference }\end{array}$ \\
\hline $\begin{array}{l}\text { Number } \\
\text { Born in Leiden - number (\%) }\end{array}$ & $\begin{array}{r}666 \\
365(56 \%)\end{array}$ & $\begin{array}{r}188 \\
114(61 \%)\end{array}$ & $\begin{array}{r}478 \\
251(53 \%)\end{array}$ & \\
\hline A ge - median (range) & $89(85-100)$ & $89(85-100)$ & $89(85-100)$ & $P=0.48$ \\
\hline $\mathrm{H}$ istory of myocardial infarction - \% & 7.8 & 8.7 & 7.5 & $P=0.57$ \\
\hline $\mathrm{H}$ istory of cerebrovascular diseases - $\%$ & 2.4 & 2.2 & 2.5 & $P=0.75$ \\
\hline H ypertension ${ }^{a}-\%$ & 22.6 & 8.7 & 28.0 & $P<0.0001$ \\
\hline Diabetes - \% & 11.8 & 9.1 & 12.9 & $P=0.13$ \\
\hline Cancer - \% & 7.1 & 10.5 & 5.8 & $P=0.014$ \\
\hline Smoking - \% & 17.3 & 51.4 & 4.1 & $P<0.0001$ \\
\hline Use of alcohol - \% & 25.3 & 49.4 & 16.1 & $p<0.0001$ \\
\hline
\end{tabular}

a ncludes a self-reported history of hypertension, diastolic blood pressure $>95 \mathrm{mmHg}$ and/or the use of anti-hypertensive medication. 
Table 2 M THFR genotype distributions and estimated mortality risks in subjects aged 85 years and over and young subjects whose families originated from the same geographical region

\begin{tabular}{|c|c|c|c|c|}
\hline \multirow{2}{*}{$\begin{array}{l}\text { M THFR } \\
\text { G enotype }\end{array}$} & \multicolumn{2}{|c|}{ Subjects } & \multirow{2}{*}{$\begin{array}{c}\text { M ortality } \\
\text { Risk }(95 \% \text { Cl) }\end{array}$} & \multirow{2}{*}{ Test for trend } \\
\hline & Elderly (\%) & Young ${ }^{a}(\%)$ & & \\
\hline \multicolumn{5}{|l|}{ all subjects } \\
\hline ala/ala & $176(48.2 \%)$ & $100(40.0 \%)$ & 1 & \\
\hline ala/val & $157(43.0 \%)$ & $119(47.6 \%)$ & $1.3(0.9-1.9)$ & \\
\hline val/val & $32(8.8 \%)$ & $31(12.4 \%)$ & $1.7(1.0-3.0)$ & $P=0.028$ \\
\hline \multicolumn{5}{|l|}{ men only } \\
\hline ala/ala & $55(48.2 \%)$ & $50(36.0 \%)$ & 1 & \\
\hline ala/val & $54(47.4 \%)$ & $72(51.8 \%)$ & $1.5(0.9-2.5)$ & \\
\hline val/val & $5 \quad(4.4 \%)$ & $17(12.2 \%)$ & $3.7(1.3-10.9)$ & $P=0.011$ \\
\hline \multicolumn{5}{|l|}{ women only } \\
\hline ala/ala & $121(48.2 \%)$ & $50(45.0 \%)$ & 1 & \\
\hline ala/val & $103(41.0 \%)$ & $47(42.3 \%)$ & $1.1(0.7-1.8)$ & \\
\hline $\mathrm{val} / \mathrm{val}$ & $27(10.8 \%)$ & $14(12.6 \%)$ & $1.3(0.6-2.6)$ & $P=0.51$ \\
\hline
\end{tabular}

a $\mathrm{M}$ edian age: 31 years (range 18-40); ${ }^{\mathrm{M}}$ ortality risks and $95 \% \mathrm{Cls}$ were estimated with the exposure odds ratio.

young men $\left(\chi_{d f}^{2}=1=6.40 ; P\right.$ for trend $\left.=0.011\right)$, but similar in elderly and young women $\left(\chi_{\mathrm{df}=1}^{2}=0.42\right.$; $\mathrm{P}$ for trend $=0.51$ ) (Table 2).

M ortality risks were estimated on the basis of the MTHFR genotype distributions in elderly and young subjects. The mortality risks associated with the ala/val and the val/val genotype were estimated at 1.3-fold $(95 \% \mathrm{Cl}, 0.9-1.9)$ and 1.7 -fold $(95 \% \mathrm{Cl}, 1.0-3.0)$ increases, respectively (Table 2). The mortality risk for men carrying the val/val genotype compared with those carrying the ala/ala genotype was estimated at 3.7 (95\% $\mathrm{Cl}, 1.3-10.9)$, whereas an increased mortality risk was virtually absent in women.

The elderly subjects were the survivors of a cohort born in Leiden between 1887 and 1901. Therefore an investigation was made of whether the young control population was likely to represent the L eiden genotype distribution of two generations earlier. The MTHFR genotype distribution in control subjects was independent of the number of grandparents born in Leiden (Table 3). This indicates that the selection criterion for the control population (i.e. either two Leiden-born parents or one Leiden-born parent and the other born

Table 3 M THFR genotype distribution in young subjects dependent on their number of grandparents born in L eiden

\begin{tabular}{|c|c|c|c|c|}
\hline \multirow{2}{*}{$\begin{array}{l}\text { M TH FR } \\
\text { genotype }\end{array}$} & \multicolumn{4}{|c|}{ Number of grandparents born in L eiden } \\
\hline & $\begin{array}{l}1 \text { or more } \\
(n=203)\end{array}$ & $\begin{array}{c}2 \text { or more } \\
(n=178)\end{array}$ & $\begin{array}{c}3 \text { or more } \\
(n=120)\end{array}$ & $\begin{array}{c}4 \\
(n=76)\end{array}$ \\
\hline ala/ala & $38.4 \%$ & $39.3 \%$ & $44.2 \%$ & $40.8 \%$ \\
\hline $\mathrm{a} / \mathrm{a} / \mathrm{val}$ & $49.8 \%$ & $48.3 \%$ & $43.3 \%$ & $47.4 \%$ \\
\hline val/val & $11.8 \%$ & $12.4 \%$ & $12.5 \%$ & $11.8 \%$ \\
\hline
\end{tabular}

within $12 \mathrm{~km}$ of Leiden) had been strict enough to obtain a population representing past L eiden genotype frequencies.

\section{Prospective Follow-up Study}

D uring the 10-year follow-up period, 591 (89\%) deaths occurred in the complete 85-plus cohort investigated in this study ( $n=666$; two subjects were lost to follow up). The cumulative survival of men and women stratified according to MTHFR genotype is shown in Figure 1. $M$ en carrying the val/val genotype survived for a shorter time ( $P$ log-rank $=0.020$ ). The median survival time of this group was 11 months compared with 38 months and 36 months for men with ala/ala and ala/ val genotype, respectively. A mong women, the MTHFR mutation was not associated with a difference in life expectancy $(P$ log-rank $=0.16)$.

O verall, the ala/val and val/val genotypes were not associated with an increased mortality risk (gender and age-adjusted relative risk, 0.9 [95\% Cl, 0.7-1.0] and 0.9 [ $95 \% \mathrm{Cl}, 0.6-1.2]$, respectively). H owever, men homozygous for the mutation, but not heterozygous men, had a significantly increased mortality risk compared with men carrying the ala/ala genotype (age-adjusted relative risk, $2.0[95 \% \mathrm{Cl}, 1.1-3.9]$ ) (Table 4). This mortality risk did not appreciably change when adjusted for smoking, alcohol consumption, hypertension and diabetes (relative risk, $2.0[95 \% \mathrm{Cl}$, 0.9-4.4]). A mong women, the MTHFR mutation was associated with marginally lower mortality risks, which bordered on the significant.

In the elderly cohort, the M THFR mutation was not associated with a self-reported history of myocardial infarction or cerebrovascular disease (data not shown). 
The mutation was also not associated with cardiovascular mortality either in men or women (Table 4). The mortality risk from cancer, however, was significantly higher among men with the val/val genotype (ageadjusted relative risk, 4.2 [95\% Cl, 1.3-13.5]), whereas among women carrying the val/val genotype the risk was not significantly different.

\section{Discussion}

In this study we have explored the possible detrimental effects of a disturbed methionine/homocysteine metabolism. This was done by investigating the association of the common MTHFR ala-to-val mutation with mortality in a cohort of men and women born between 1887-1901. It can be assumed that carriers of the MTHFR mutation, in general, have a mildly disturbed methionine/homocysteine metabolism during their whole life. The effect of the MTHFR mutation on mortality before the age of 85 was studied in a crosssectional design that accounted for possible geographical differences in the MTH FR genotype distribution. The MTHFR mutation was associated with an increased mortality risk as indicated by an underrepresentation of the mutation in elderly compared with young subjects. The association was predominantly present in men. M en homozygous for the mutation had about a 4-fold increased mortality risk. 0 ur findings are supported by the reduction of the val/val genotype
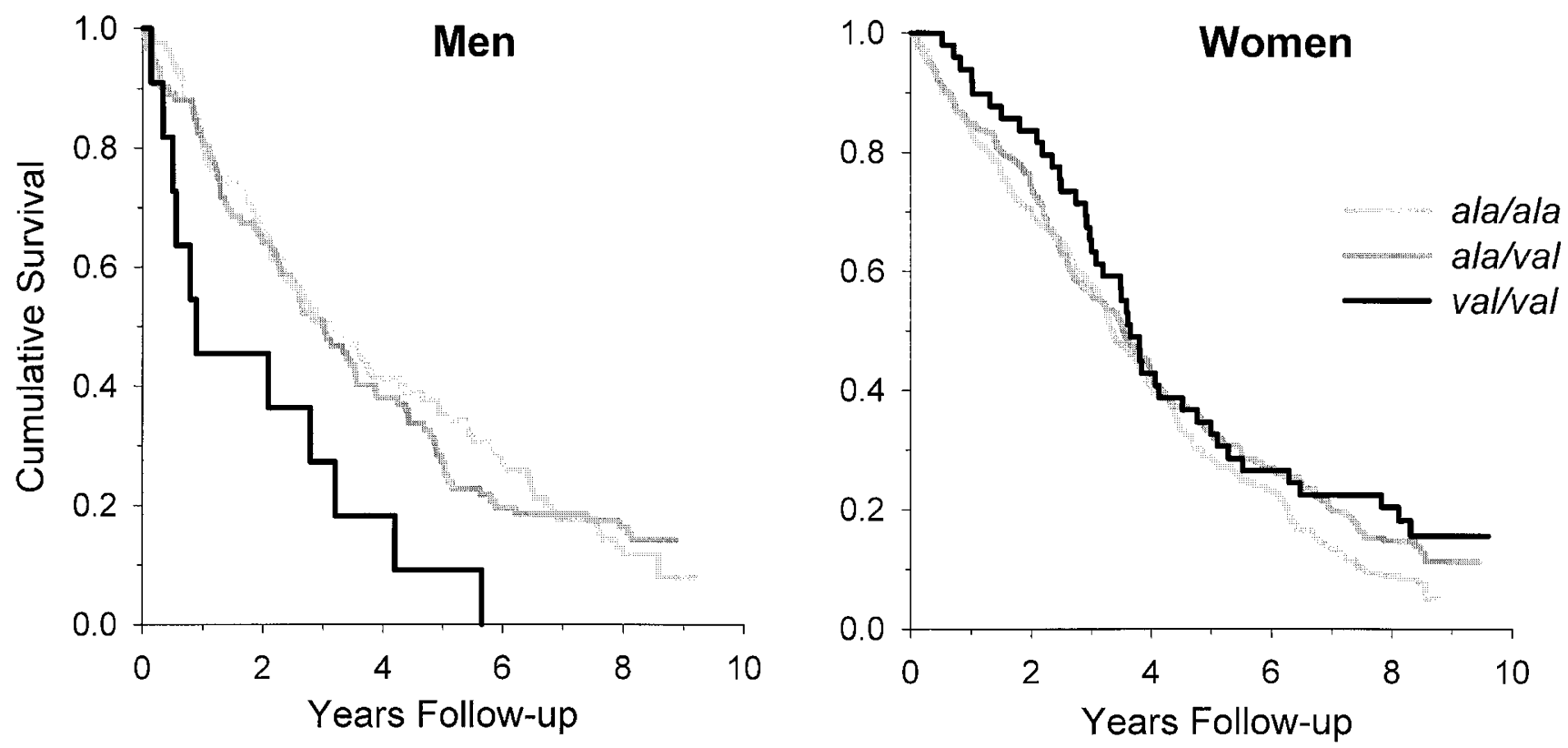

Figure 1 Kaplan-M eier estimate of 10-year cumulative survival according to MTHFR genotype for men and women aged 85 years and over.

Table 4 A II-cause and cause-specific 10-year mortality risks according to M THFR genotype in subjects aged 85 years and over

\begin{tabular}{|c|c|c|c|c|c|c|c|c|c|}
\hline \multirow[t]{2}{*}{$\begin{array}{l}\text { M THFR } \\
\text { genotype }\end{array}$} & \multirow[t]{2}{*}{$\begin{array}{l}\text { Number of } \\
\text { subjects }\end{array}$} & \multicolumn{2}{|c|}{ All causes } & \multicolumn{2}{|c|}{$\begin{array}{l}\text { Cardiovascular } \\
\text { disease }\end{array}$} & \multicolumn{2}{|c|}{ Cancer } & \multicolumn{2}{|c|}{$\begin{array}{l}\text { Infectious } \\
\text { disease }\end{array}$} \\
\hline & & $R R$ & $(95 \% \mathrm{Cl})^{a}$ & $\mathrm{RR}$ & $(95 \% \mathrm{Cl})$ & $R R$ & $(95 \% \mathrm{Cl})$ & $\mathrm{RR}$ & $(95 \% \mathrm{Cl})$ \\
\hline \multicolumn{10}{|l|}{ men } \\
\hline ala/ala & 85 & 1 & & 1 & & 1 & & 1 & \\
\hline ala/val & 92 & 1.0 & $(0.7-1.4)$ & 0.7 & $(0.4-1.2)$ & 1.2 & $(0.6-2.6)$ & 1.1 & $(0.4-3.1)$ \\
\hline $\mathrm{val} / \mathrm{val}$ & 11 & 2.0 & $(1.1-3.9)$ & 0.7 & $(0.2-3.1)$ & 4.2 & $(1.3-13.5)$ & 1.4 & $(0.1-14.6)$ \\
\hline \multicolumn{10}{|l|}{ women } \\
\hline ala/ala & 223 & 1 & & 1 & & 1 & & 1 & \\
\hline ala/val & 204 & 0.8 & $(0.7-1.0)$ & 0.9 & $(0.7-1.3)$ & 0.9 & $(0.6-1.5)$ & 0.6 & $(0.3-1.2)$ \\
\hline $\mathrm{val} / \mathrm{val}$ & 49 & 0.7 & $(0.5-1.0)$ & 0.9 & $(0.5-1.5)$ & 0.5 & $(0.2-1.4)$ & 0.3 & $(0.1-1.3)$ \\
\hline
\end{tabular}

$\mathrm{a}_{\mathrm{R}} \mathrm{R}$ indicates the mortality risk as estimated with a Cox proportional hazard model adjusted for age at baseline. 
observed in French centenarians $\mathrm{s}^{17}$ and the gradual decline in prevalence of the val/val genotype with increasing age found in Japanese subjects, ${ }^{36}$ whereas two other cross-sectional studies ${ }^{37,38}$ did not observe a decreased prevalence of the MTHFR mutation in old age. The design of these studies, however, did not extensively check for geographical variations in genotype distribution or gene-pool effects. A Iso, population differences in factors modulating the effect of the MTHFR mutation may have contributed to these variable results.

Mortality after the age of 85 years was examined during a 10-year follow-up period. The mutation conferred a 2 -fold increased mortality risk in elderly men homozygous for the mutation, but not in women. The prospective follow-up study thus confirms the increased mortality risk associated with the MTHFR mutation observed in our cross-sectional analysis.

The relation of the MTHFR mutation with risk of cardiovascular disease is controversial. Some studies reported an association of the val/val genotype with an increased risk of cardiovascular disease, ${ }^{4,14,18,23}$ whereas in other studies evidence for this relation was absent. ${ }^{10,15,16,19,21,24-28}$ Here, we show that the MTHFR mutation was associated with an increased mortality in men before and after the age of 85 years but, by design, no data were available concerning the causes of death in middle age. 0 ver the age of 85 years, cardiovascular diseases did not contribute to the increased mortality of men with the val/val genotype. Although half the elderly men and women died from cardiovascular disease (data not shown), the mutation was not associated with increased cardiovascular disease mortality. Two interpretations are compatible with these findings. The MTHFR mutation is not related to mortality due to cardiovascular diseases in middle and old age. A Iternatively, carriers of the mutation are subject to an increased cardiovascular disease mortality before the age of 85 years, which has led to the selective survival of carriers who are less susceptible to cardiovascular diseases.

A Ithough the numbers were small, we found that the increased mortality risk of men aged 85 years and over with the val/val genotype was largely explained by an increased risk of death due to cancer. A $n$ association between the MTHFR mutation and the risk of colorectal cancer was reported in two other prospective studies. U nited States health professionals ${ }^{12}$ and physicians $^{29}$ carrying the val/val genotype were found to have a reduced risk of colorectal cancer. This protective effect was abolished by moderate alcohol consumption, probably because alcohol depletes folate. ${ }^{39}$ It is not clear how the opposite effects of the MTHFR mutation on cancer risk in our population-based study and the previous studies can be explained. The MTHFR mutation may increase the risk of cancer especially in groups with a low folate intake, such as the elderly, rather than in well-nourished health professionals and physicians. ${ }^{12,29}$

From the present data it remains unclear why men carrying the MTHFR mutation were at an increased risk of mortality, whereas mortality in women carrying the mutation was not affected. Hormonal differences with respect to oestrogens are a less likely explanation for the association observed, since the genderdependent association with mortality persisted after the age of 85 years when women are well beyond the menopause. Influence of oestrogens on the methionine/ homocysteine metabolism is further refuted by the absence of a long-term effect of hormone replacement therapy on the level of plasma homocysteine. ${ }^{40}$ Since the level of plasma folate is a critical modulator of the MTHFR mutation, differences in the level of plasma folate between men and women may also have contributed to the gender-dependent association. A previous study in elderly subjects, however, reported no difference in the level of plasma folate between men and women despite the higher folate intake of women. ${ }^{41}$

A clear gender difference was present with respect to smoking habits and alcohol consumption; $51 \%$ of the men and only $4 \%$ of the women reported smoking, and $49 \%$ of the men reported alcohol consumption vs $16 \%$ of the women. Smoking is associated with elevated plasma homocysteine, ${ }^{15,42}$ whereas alcohol is a methyl group antagonist and depletes folate. ${ }^{39}$ It may be hypothesised that the combined effects of smoking, alcohol consumption and the MTHFR mutation on the methionine/homocysteine metabolism might have led to an increased mortality risk in men but not in women. E specially among individuals from the 1887-1901 birth cohort, who were middle aged during the 1930s to 1960s; the majority of men smoked, whereas among women smoking was uncommon.

In conclusion, our data suggest that homozygosity for the M THFR ala-to-val mutation increases the mortality risk in men both in middle and old age. O ur study does not reveal the causes of death contributing to the increased mortality risk in middle age, but suggests that cancer rather than cardiovascular disease may be the primary cause of death in elderly men carrying the val/ 
val genotype. Larger prospective population-based studies are needed to confirm the effect of the MTHFR mutation on all-cause and cancer mortality. Interventions starting at a young age to restore a balanced methionine/homocysteine metabolism may prove to be beneficial to carriers of the val/val genotype.

\section{Acknowledgements}

We wish to thank the $R$ ed Cross Blood Bank Leidsenhage, and especially Marjo Dirven, for assembling the control population, and the Central Bureau of Statistics for generously making available the mortality statistics and database linking. This study was supported by grant 94.047 from the $\mathrm{N}$ etherlands H eart Foundation and grant A G 06354 from the U S National Institutes of $\mathrm{H}$ ealth.

\section{References}

1 Boushey CJ, Beresford SA A, O menn G S, M otulsky A G: A quantitative assessment of plasma homocysteine as a risk factor for vascular disease. JAMA 1995; 274: 1049-1057.

2 Nygård $O, N$ ordrehaug J $E$, R efsum $H$, U eland $P M$, Farstad M, Vollset SE: Plasma homocysteine levels and mortality in patients with coronary artery disease. N E ngl J Med 1997; 337: 230-236.

3 M iller J W, Nadeau M R, Smith D, Selhub J : Vitamin B-6 deficiency vs folate deficiency: comparison of responses to methionine loading in rats. Am J Clin Nutr 1994; 59: 1033-1039.

4 Gallagher PM, Meleady R, Shields DC et al: Homocysteine and risk of premature coronary heart disease. Evidence for a common gene mutation. Circulation 1996; 94: 2154-2158.

5 M udd SH, Levy HL, Skovby F : D isorders of transsulfuration. In Scriver CR, B eaudet A L, Sly WS, Valle D (eds). The $M$ etabolic B asis of Inherited Disease, 6th edn. New York, 1989, pp 693-734.

6 R osenblatt D S: I nherited disorders of folate transport and metabolism. In: Scriver CR, B eaudet A L, Sly W S, Valle D (eds). The M etabolic Basis of Inherited D isease, 6th edn. New York, 1989, pp 2049-2064.

7 Frosst $\mathrm{P}, \mathrm{B}$ lom $\mathrm{H}$ J, M ilos $\mathrm{R}$ et al: A candidate genetic risk factor for vascular disease: a common mutation in methylenetetrahydrofolate reductase. N at G enet 1995; 10: 111-113.

8 de Franchis $\mathrm{R}, \mathrm{M}$ ancini $\mathrm{FP}$, d'A ngelo $\mathrm{A}$ et al: Elevated total plasma homocysteine and $677 \mathrm{C} \rightarrow T$ mutation of the 5,10-methylenetetrahydrofolate reductase gene in thrombotic vascular disease. Am J Hum Genet 1996; 59: 262-264.

9 Jacques PF, Bostom AG, Williams RR et al: Relation between folate status, a common mutation in methylenetetrahydrofolate reductase, and plasma homocysteine concentrations. Circulation 1996; 93: 7-9.
10 Wilcken $D E L$, Wang $X L$, Sim AH, McCredie $R M$ : $D$ istribution in healthy and coronary populations of the methylenetetrahydrofolate reductase (MTHFR) $\mathrm{C}_{677} \mathrm{~T}$ mutation. Arterioscler Thromb Vasc Biol 1996; 16: 878-882.

$11 \mathrm{H}$ armon D L, Woodside Y V, Y arnell J W et al: The common 'thermolabile' variant of methylene tetrahydrofolate reductase is a major determinant of mild hyperhomocysteinaemia. Q J M ed 1996; 89: 571-577.

12 Chen J, Giovannucci $E$, Kelsey $K$ et al: A methylenetetrahydrofolate reductase polymorphism and the risk of colorectal cancer. Cancer Res 1996; 56: 4862-4864.

13 Guttormsen A B, U eland PM, Nesthus I et al: Determinants and vitamin responsiveness of intermediate hyperhomocysteinemia ( $\geq 40$ umol/liter). J Clin Invest 1996; 98: 2174-2183.

14 Izumi M, I wai N, Ohmichi N, Nakamura $Y$, Shimoike $\mathrm{H}$, K inoshita M : M olecular variant of 5,10-methylenetetrahydrofolate reductase is a risk factor of ischemic heart disease in the Japanese population. A therosclerosis 1996; 121: 293-294.

$15 \mathrm{Ma}$ J, Stampfer MJ, Hennekens $\mathrm{CH}$ et al: M ethylenetetrahydrofolate reductase polymorphism, plasma folate, homocysteine and the risk of myocardial infarction in U S physicians. Circulation 1996; 94: 2410-2416.

16 Deloughery TG, Evans A, Sadeghi A et al: Common mutation in methylenetetrahydrofolate reductase. Correlation with homocysteine metabolism and late-onset vascular disease. Circulation 1996; 94: 3074-3078.

17 Faure-D elanef L, Q uéré I, Chassé J F et al: M ethylenetetrahydrofolate reductase thermolabile variant and human longevity. A m J H um G enet 1997; 60: 999-1001.

18 Morita H, Taguchi JI, Kurihara H et al: Genetic polymorphism of 5,10-methylenetetrahydrofolate reductase (MTHFR) as a risk factor for coronary artery disease. Circulation 1997; 95: 2032-2036.

19 K luijtmans LA J, K astelein JJ P, L indemans J et al:Thermolabile methylenetetrahydrofolate reductase in coronary artery disease. Circulation 1997; 96: 2573-2577.

20 van der Put NMJ, Steegers-Theunissen R PM, Frosst P et al: M utated methylenetetrahydrofolate reductase as a risk factor for spina bifida. L ancet 1995; 346: 1070-1071.

21 Verhoef $P$, Kok FJ, K luijtmans LA J et al: The $677 \mathrm{C} \rightarrow T$ mutation in the methylenetetrahydrofolate reductase gene: associations with plasma total homocysteine levels and risk of coronary atherosclerotic disease. A therosclerosis 1997; 132: 105-113.

22 Malinow M R, Nieto FJ, K ruger WD et al: The effects of folic acid supplementation on plasma total homocysteine are modulated by multivitamin use and methylenetetrahydrofolate reductase genotypes. A rterioscler Thromb Vasc Biol 1997; 17: 1157-1162.

23 K luijtmans LA J, van den H euvel LPWJ, B oers GHJ et al: Molecular genetic analysis in mild hyperhomocysteinemia: a common mutation in the methylenetetrahydrofolate reductase gene is a genetic risk factor for cardiovascular disease. A m J H um G enet 1996; 58: 35-41.

24 A dams M, Smith PD, M artin D, Thompson JR, Lodwick D, Samani NJ: G enetic analysis of thermolabile methylenetetrahydrofolate reductase as a risk factor for myocardial infarction. Q J Med 1996; 89: 437-444. 
25 Schmitz C, Lindpaintner K, Verhoef P, Gaziano J M, Buring $\mathrm{J}$ : Genetic polymorphism of methylenetetrahydrofolate reductase and myocardial infarction. Circulation 1996; 94: 1812-1814.

26 Brugada $R, M$ arian A J: A common mutation in methylenetetrahydrofolate reductase gene is not a major risk of coronary artery disease or myocardial infarction. A therosclerosis 1997; 128: 107-112.

27 van B ockxmeer FM, M amotte CD S, Vasikaran SD, Taylor R R : M ethylenetetrahydrofolate reductase gene and coronary artery disease. Circulation 1997; 95: 21-23.

28 Brulhart MC, Dussoix P, Ruiz G, Passa P, Friguel Ph, James RW: The (A la-Val) mutation of methylenetetrahydrofolate reductase as a genetic risk factor for vascular disease in non-insulin-dependent diabetic patients. A m J H um G enet 1997; 60: 228-229.

$29 \mathrm{Ma}$ J, Stampfer MJ, Giovannucci $\mathrm{E}$ et al: Methylenetetrahydrofolate reductase polymorphism, dietary interactions, and risk of colorectal cancer. Cancer Res 1997; 57: 1098-1102.

30 Lagaay A M, D'A maro J, Ligthart GJ, Schreuder GMT, Van Rood JJ, Hijmans W: Longevity and heredity in humans: A ssociation with Human Leucocyte Antigen phenotype. Ann N Y A cad Sci 1991; 621: 78-89.

31 Lagaay A M, van der M eij J C, Hijmans W: Validation of medical history taking as part of a population-based survey in subjects aged 85 years and over. B r M ed J 1992; 304: 1091-1092.

32 Sambrook J, Fritsch EJ, M aniatis T (eds): Molecular Cloning: a Laboratory Manual, 2nd edn. Cold Spring $\mathrm{H}$ arbor Laboratory Press: Cold Spring $\mathrm{H}$ arbor, 1989, vol 2.

33 World H ealth O rganization: I nternational Classification of $D$ iseases: $M$ anual of the International Statistical Classification of Diseases, Injuries, and Causes of D eath. World H ealth Organization: Geneva, 1977.
34 Weverling-Rijnsburger AWE, Blauw GJ, Lagaay AM, $K$ nook D L, M einders A E , Westendorp R G J : Total cholesterol and the risk of mortality in the oldest old. L ancet 1997; 350: 1119-1123.

35 R othman KJ: M odern E pidemiology. Little, B rown: Boston, 1986.

36 M atsushita S, M uramatsu T, A rai $H, M$ atsui T, H iguchi S: The frequency of the methylenetetrahydrofolate reductase-gene mutation varies with age in the normal population. A m J H um G enet 1997; 61: 1459-1460.

37 Galinsky D, Tysoe C, Brayne CE et al: A nalysis of the apo $E$ /apo $C-1$, angiotensin converting enzyme and methylenetetrahydrofolate reductase genes as candidates affecting human longevity. A therosclerosis 1997; 129: 177-183.

$38 \mathrm{H}$ armon DL, M CM aster D, Shields DC, Whitehead A S, R ea IM : M THFR thermolabile genotype frequencies and longevity in Northern I reland. A therosclerosis 1997; 131: 137-138.

39 Shaw S, Jayatilleke E, H erbert V, Colman N : C leavage of folates during ethanol metabolism. R ole of acetaldehyde/ xanthine oxidase-generated superoxide. B iochem J 1989; 257: 277-280.

40 van der Mooren MJ, D emacker PNM, Blom HJ, de Rijke $Y B, R$ olland $R$ : The effect of sequential three-monthly hormone replacement therapy on several cardiovascular risk estimators in postmenopausal women. Fertil Steril 1997; 67: 67-73.

41 Selhub J, Jacques PF, Wilson PWF, R ush D, R osenberg IH : $\checkmark$ itamin status and intake as primary determinants of homocysteinemia in an elderly population. JAMA 1993; 270: 2693-2698.

42 Nygård $\mathrm{O}$, Vollset $\mathrm{SE}$, Refsum $\mathrm{H}$ et al: Total plasma homocysteine and cardiovascular risk profile. The H ordaland H omocysteine Study. JA M A 1995; 274: 1526-1533. 